\title{
Assessing the Financial Health Status of Small Scale Poultry Businesses in Delta State, Nigeria
}

\author{
D. E. Idoge ${ }^{1} \&$ C. O. Chukwuji ${ }^{1}$ \\ ${ }^{1}$ Department of Agricultural Economics and Extension, Delta State University, Asaba Campus Delta State, \\ Nigeria \\ Correspondence: D. E. Idoge, Department of Agricultural Economics and Extension, Delta State University, \\ Asaba Campus Delta State, Nigeria. E-mail: daveidoge@gmail.com
}

\author{
Received: March 25, 2014 Accepted: August 10, 2014 Online Published: August 27, 2014 \\ doi:10.5539/sar.v3n4p9 URL: http://dx.doi.org/10.5539/sar.v3n4p9
}

\begin{abstract}
The study investigated the financial health status of small scale poultry businesses in Delta State, Nigeria using Altman's Z-score model. The empirical study was undertaken to assess the solvency and hence future survivability of small scale poultry enterprises in the State. Financial data were extracted from three years (2010 - 2012) financial statements of 125 small scale poultry farms purposively selected from farms operating in the State and incorporated with the Nigerian Corporate Affairs Commission as limited liability agribusinesses. Descriptive statistics which include computed financial ratios, frequency distributions, percentages and tables were applied to analyze the content of the financial statements and Altman's Z-scores' were computed for each sampled farm for the three year period. The study shows that in $2010,47.8$ percent of farm enterprises had Z-scores between minus 0.60 to 1.55 . In 2011 and 2012, 44.8 percent and 42.4 percent, respectively of the farms had Z-scores between negative 0.60 and 1.55 . The study further indicates that 28 percent, 27 percent and 30.4 percent in 2010, 2011 and 2012, respectively, of the sampled farms had computed Z-scores between 2.64 and 4.79 farms. The study recommends the use of Altman's Z-score by small scale investors as a technique for monitoring the financial health of their agribusinesses to prevent the ugly consequences of bankruptcy and liquidation.
\end{abstract}

Keywords: financial health status, financial statements, financial ratios and Z-score

\section{Introduction}

\subsection{Statement of Problem}

Poultry Businesses particularly small scale farms in Delta State Nigeria, continues to face undesirable levels of chronic vulnerability insolvency and liquidation. The phenomenon has been due to unfavourable climatic conditions, economic shocks such as increasing prices of food and materials, high cost of labour, competition from inputs, poor market infrastructure, corruption and financial mismanagement. These conditions have adversely affected the ability of small scale farmers to cope and manage their farms in a sustainable manner. The increasing complexity of the situation, coupled with the decreasing ability of small scale poultry farmers to respond to shocks using their own resources and management skills, demands and heightened sophistication (breath, dept, and time) in deliberate assessment and analysis of the extent to which small scale poultry farmers can manage this complex set of risks and still maintain sound and healthy financial status to escape the dangers of corporate bankruptcy and failure. Altman's z-score has been used to assess the financial health status of firms with the aim of signaling as early as possible warning signs of financial distress, to prevent, mitigate and respond to negative outcomes such as bankruptcy, liquidation or eventual failure using Altman's z-score.

\subsection{Objectives of the Study}

The objectives of this paper are to assess the financial health status of small scale poultry businesses in Delta State, Nigeria and to identify the population of farms requiring financial surgery.

\subsection{Significance of Study}

Many a food security crises, famine or microcredit empowerment programme failures has taken policy makers and stakeholders by surprise because of the lack of adequate information necessary to detect early warning signals on farm firms distress or failures. Currently, there is an information vacuum on the financial health status 
of small scale poultry businesses in the study area. The study will strengthen sectoral information and data base on poultry farms financial health status and provide a foundation for monitoring and assessing the level of intervention needed in this era of the Nation's Agricultural transformation agenda.

\subsection{Literature Review}

Hayes, Hodge and Hughes (2010), showed the efficacy of the Altman's Z- score in predicting financial distress in retail firms. In eight comparisons, the Z-score accurately predicted bankrupt firms $94 \%$ of the time and accurately predicted firms with financial distress $90 \%$ of the time.

Satish and Janakiram (2011), used Altman's Z-score model to predict the failure of customers. The study showed that Altman model performed well in predicting failures. Alkhatib and Bzour (2011), investigated the predictability of corporate bankruptcy of Jordanian listed companies using Altman and Kida models. The study included sample companies listed on the Jordanian stock exchange that were liquidated during the period 1990-2006. It also set out to find which model is favourable in predicting bankruptcy. The study showed the ability of the Altman Z-score model to predict the bankruptcy of Jordanian companies during the five years preceding the bankruptcy incident.

Li (2012), examined the accuracy of various Z-score models in predicting corporate bankruptcy from 2008 through 2011 in the United States. He concluded that although the original Z-score model was developed for manufacturing firms, it performed equally well in predicting bankruptcy for non-manufacturing companies.

Sulphey and Nisa (2013), assessed the solvency position of 220 companies listed in the BSE Cap index using Z-score. The results showed that only 79 companies were in the safe zone, 117 companies were in the grey zone and 24 in the distress zone.

Selvam (2004) made a study to predict the financial health and viability of India Cements Ltd. They concluded that the cement company was on the verge of financial collapse. Krishna (2005) using Altman's Z score model measured the financial distress of IDBI and predicted that the company is not in the health zone, and is likely to be insolvent in the near future. Dheenadhyalan (2008) used the model to predict the financial health of SAIL. The $\mathrm{Z}$ score showed a rising trend throughout the study period, and it was concluded that the financial health of the SAIL was good.

A study by Ramaratnam and Jayaraman (2010) analyzed and predicted the financial health of five selected companies in the Indian industry using Altman's Z - Score. The study revealed that all the five companies were financially sound during the study period. Another study by Bhatt (2012) investigated the ability of three versions of the model for distress prediction in the Indian markets. The study was conducted on four selected companies, belonging to various sectors. The results proved that the models have remarkable degrees of accuracy in distress prediction.

\subsection{Related Studies in Nigeria}

Olaniyi (2007), evaluated the susceptibility of Nigerian banks to failure with a view to discriminating between sound and unhealthy banks as a guide to investment decisions using First Bank and Trade Bank as case studies. He concluded that the model measured accurately the potential of failure of unhealthy banks.

Uchenna and Okelue (2012), applied multi discriminant analysis model (MDA) as proposed by Altman in 1968 to a group of failed and healthy banks in Nigeria to ascertain if MDA is a veritable tool to predict business failure in the Nigerian banking industry. The results showed that MDA is a veritable tool for assessing the financial health of banks.

Onyeiwu (2012), examined the applicability of the multiple discriminant analysis by Altman to twenty manufacturing companies in Nigeria. This study concluded that the application of multiple discriminant analysis was relevant to the Nigerian business environment.

\subsection{Theoretical Framework}

The concept of resource use efficiency in production activities provides the theoretical framework for this study. The productivity of resource used is measured by relating input used to output obtained. Optimal productivity of resources implies an efficient utilization of resources in the production process. Efficiency refers to the attainment of production goals with minimal waste. It is the effectiveness with which inputs are transformed into outputs. Efficiency could take the form of technical efficiency, allocative efficiency or economic efficiency. Although firms differ one from another to a considerable degree in terms of the nature of business, capital structure, personnel employed, risk and technology, one thing they have in common is a basic mechanism involving the conversion of resources (funds) into saleable products (poultry) and back into liquid form. Funds 
refer to the value embedded in assets. Funds are usually received into a business initially in the form of cash and though part of this cash may be used to purchase fixed assets, part will be used to pay wages, expenses and buy materials and/or to buy trading stock direct, depending on the nature of the business. The funds have not ceased to exist merely because cash has been transformed into assets. They are now embedded in the assets. These resource conversion processes have implications for the financial health status of a business. A business that uses resources efficiently is more likely to experience a better financial health status than one that uses resources inefficiently.

\section{Methodology}

The data required for analyzing the financial health status of small scale poultry businesses in Delta State were collected for a three year period i.e. 2010, 2011 and 2012. Thus, the study covers a period of three accounting years 2010, 2011 and 2012. A sample of 125 small scale poultry businesses was purposively selected for the study. The sampled farms were randomly selected from the list of poultry farm businesses incorporated as private limited liability companies with the Corporate Affairs Commission. The choice of private limited liability farm businesses was to ease the problem of data collection since this category of farm enterprises are required by law to prepare annual financial reports for the purpose of rendering annual returns. Thus data were derived from the financial statements (Balance sheets and income statements) of sampled farm enterprises. The financial data extracted include working capital, sales, total assets, earnings before interest and tax, market value of equity and book value of total liability (debts).

Descriptive statistics which include computed financial ratios, frequency distributions, percentages and tables were applied to analyze the content of the financial statements. In order to use Altman's Z-score model in predicting financial health, Z-scores' were computed for each sampled farm for the three year period. Based on the computed Z-scores and using Altman's criterion, the poultry farm businesses were then classified into financially healthy, unhealthy or cannot say (Grey).

\subsection{Model Specification}

The specified analytical technique for this study is the Altman's discriminant function model and is as follows:

$$
\mathrm{Z}=.012 \mathrm{X}_{1}+.014 \mathrm{X}_{2}+.033 \mathrm{X}_{3}+.006 \mathrm{X}_{4}+.999 \mathrm{X}_{5}
$$

Where $\mathrm{X}_{\mathrm{I}}=$ Working capital/Total assets

$\mathrm{X}_{2}=$ Retained Earnings/Total assets

$\mathrm{X}_{3}=$ Earnings before interest and taxes/Total assets

$\mathrm{X}_{4}=$ Market value equity/Book value of total debt

$\mathrm{X}_{5}=$ Sales/Total assets

$\mathrm{Z}=$ Overall Index

Working Capital/Total Assets $\left(\mathbf{X}_{\mathbf{1}}\right)$. The Working capital/Total assets ratio is a measure of the net liquid assets of the poultry farm enterprise relative to the total capitalization. Working capital is defined as the difference between current assets and current liabilities. Ordinarily, a farm experiencing consistent operating losses will have shrinking current assets in relation to total assets.

Retained Earnings/Total Assets $\left(\mathbf{X}_{2}\right)$. This is a measure of cumulative profitability over time. The age of a firm is implicitly considered in this ratio. For example, a relatively young firm will probably show a low RE/TA ratio because it has not had time to build up its cumulative profits. Therefore, it may be argued that the young firm is somewhat discriminated against in this analysis, and its chance of being classified as bankrupt is relatively higher than another, older firm, ceteris paribus. The incidence of failure is much higher in a firm's earlier years.

Earnings Before Interest and Taxes/Total Assets $\left(\mathbf{X}_{3}\right)$. This ratio is calculated by dividing the total assets of a firm into its earnings before interest and tax reductions. It is a measure of the true productivity of the firm's assets, abstracting from any tax or leverage factors. Since a firm's ultimate existence is based on the earning power of its assets, this ratio appears to be particularly appropriate for studies dealing with corporate insolvency/failure. Furthermore, insolvency in a bankruptcy sense occurs when the total liabilities exceed a fair valuation of the firm's assets with value determined by the earning power of the assets.

Market Value of Equity/Book Value of Total Debt $\left(\mathbf{X}_{4}\right)$. Equity is measured by the combined market value of all shares of common stock, while debt includes both current and long-term. The measure shows how much the firm's assets can decline in value (measured by market value of equity plus debt) before the liabilities exceed the 
assets and the farm firm becomes insolvent.

Sales/Total Assets $\left(\mathbf{X}_{\mathbf{5}}\right)$. The capital-turnover ratio is a standard financial ratio illustrating the sales generating ability of the firm's assets. It is one measure of management's capability in dealing with competitive conditions.

\subsection{Altman's Z-score Criterion}

Altman presented three zones of discrimination in his model, as stated below:

(i) Z-score greater than 2.9 classifies healthy units with lower probability of failure.

(ii) Z-score greater than 1.81 and less than 2.9 represents grey area with both bankruptcy (failure) and non-bankruptcy (non-failure) possibilities.

(iii) Z-score less than 1.81 indicates financially distressed and bankruptcy units.

The Z-score offers an excellent measure for evaluating the financial health of a firm. The lower the score the greater chance of failure. The score, which combines mutually exclusive ratios into a group helps overcome the shortcomings of individual financial ratio analysis. The beauty of Z-score is that it provides a calculated measure based on past experience, rather than personal opinion. The Z-score provides added value and credibility to the valuation process, as it helps in evaluating the reliability statistically in addition to providing insight into relative performance and financial viability (Altman, 2000).

\section{Results and Discussion}

\section{Descriptive statistics of variables}

Table 1. Descriptive statistics of variables $(2010-2012)$

\begin{tabular}{lllll}
\hline Variables & Min. & Max. & Mean & Std. Dev. \\
\hline & $N^{\prime} 000$ & $N^{\prime} 000$ & $N^{\prime} 000$ & $N^{\prime} 000$ \\
Sales & 685 & 10,957 & 2,574 & 1,716 \\
Total Assets & 436 & 4,818 & 1,430 & 851 \\
Earnings before interest and tax (EBIT) & $-1,952$ & 1,206 & 16 & 447 \\
Retained Earnings & -974 & 696 & -8 & 360 \\
Working capital & 59 & 1,034 & 317 & 209 \\
Total Debt & -1007 & 1,069 & 24 & 365 \\
Value of Equity & -222 & 193 & -2728 & 70 \\
\hline
\end{tabular}

Table 1 shows the descriptive statistics for the variables used in the study. The minimum value of sales for the three year period $(2010$ - 2012) was $\$ 685,000.00$ while the maximum value of sales was $\$ 10,957,000.00$. The mean sales value was $\$ 2,574,000.00$ with a standard deviation of $\$ 1,716,000.00$. The minimum value of total assets was $\$ 436,000.00$ while the maximum value was $\$ 4,818,000.00$. The mean value of total assets was $\$ 1,430,000.00$ with a standard deviation of $\$ 851,000.00$. The minimum working capital had a value of $\$ 59,000.00$ and a maximum value of $\$ 1,034,000.00$. The average working capital for the three year period was $\$ 317,000.00$. Earnings before interest and tax (EBIT), retained earnings, total debt and value of equity had minimum negative values each of $\$ 1,952,000.00, \$ 974,000.00, \$ 1,007,000.00$ and $\$ 222,000.00$, respectively. The maximum value of EBIT was $\$ 1,206,000.00$. Retained earnings, total debt and value of equity had maximum values each of $\$ 696,000.00$, $\$ 1,069,000.00$, and $\$ 193,000.00$, respectively. The mean value was $\$ 16,000.00$ for EBIT, $\$ 24,000.00$ for total debt while retained earnings and equity value had negative mean values each of $\$ 8,000.00$ and $\$ 2,728,000.00$, respectively.

\section{Univariate analysis of financial ratios}

Univariate presentation and analysis of the financial ratios used in the study are presented in this section.

\section{Working capital to total assets ratio $\left(\mathbf{X}_{1}\right)$}

The minimum working capital to total assets ratio for the sampled poultry businesses for the studied period was 8 percent while maximum ratio was 47 percent. For the period, the studied farm businesses had a mean working capital to total assets ratio of 23 percent with a standard deviation of 7 percent. 
Table 2. Sampled poultry farms computed working capital/total assets ratio $\left(\mathrm{X}_{1}\right)$

\begin{tabular}{llll}
\hline & 2010 & 2011 & 2012 \\
\hline Ratio class (pooled) & No. farms (percent) & No. farms(percent) & No. farms(percent) \\
\hline $8-16$ & $20(16)$ & $22(17.6)$ & $24(19.2)$ \\
$17-24$ & $60(48)$ & $53(42.4)$ & $59(47.2)$ \\
$25-32$ & $24(19.2)$ & $39(31.2)$ & $31(24.8)$ \\
$33-40$ & $11(8.8)$ & $9(7.2)$ & $7(5.6)$ \\
$41-49$ & $10(8)$ & $2(1.6)$ & $4(3.2)$ \\
Total & $\mathbf{1 2 5 ( 1 0 0 )}$ & $\mathbf{1 2 5}(\mathbf{1 0 0})$ & $\mathbf{1 2 5}(\mathbf{1 0 0})$ \\
\hline
\end{tabular}

Source: Survey data.

Table 2 shows the computed pooled working capital to total assets ratios for the sampled poultry farm businesses. In 2010, eighty farms had working capital to total assets ratio of between 8 and 24 percent. This was equivalent to 64 percent of the sampled farm enterprises. Forty-five farms had working capital to total assets ratio of between 25 and 49 percent. This was equivalent to 36 percent of the sampled farm enterprises. In 2011, seventy-five farm businesses had working capital to total assets ratio of between 8 and 24 percent. This was equivalent to 60 percent of the 125 sampled farms. Fifty farms had ratios between 25 and 49 percent. This was equivalent to 40 percent of the sampled enterprises. In 2012, eighty-three farm businesses had working capital to total assets ratio of between 8 and 24 percent. This was equivalent to 66.4 percent of the sampled farms. Forty-two farm enterprises or 33.6 percent had between 25 and 49 percent as working capital to total assets ratio. With an average mean ratio of 23 percent for the sampled farms during the period, this ratio could be said to be adequate implying a not too bad liquidity position.

\section{Retained earnings to total assets ratio $\left(\mathbf{X}_{2}\right)$}

The sampled enterprises had a negative minimum retained earnings to total assets ratio of 37 percent and a positive maximum ratio of 33 percent. The mean ratio value was 1 percent with a standard deviation of 22 percent.

Table 3. Sampled poultry farms computed retained earnings/total assets ratio $\left(\mathrm{X}_{2}\right)$

\begin{tabular}{llll}
\hline & 2010 & 2011 & 2012 \\
\hline Ratio class & No. farms (percent) & No. farms(percent) & No. farms(percent) \\
\hline$-37--23$ & $16(12.8)$ & $20(16)$ & $15(12)$ \\
$-22--8$ & $34(27.2)$ & $42(33.6)$ & $39(31.2)$ \\
$-7-7$ & $14(11.2)$ & $129.6)$ & $7(5.6)$ \\
$8-22$ & $45(36)$ & $36(28.8)$ & $42(33.6)$ \\
$23-35$ & $16(12.8)$ & $14(11.2)$ & $22(17.6)$ \\
Total & $\mathbf{1 2 5 ( 1 0 0 )}$ & $\mathbf{1 2 5 ( 1 0 0 )}$ & $\mathbf{1 2 5 ( 1 0 0 )}$ \\
\hline
\end{tabular}

Source: Survey data.

Table 3 indicates the pooled retained earnings to total assets ratio of the sampled businesses. The table shows that in 2010, fifty of the sampled farm units had negative retained earnings to total assets ratio of between 37 and 8 percent. This was equivalent to 40 percent of the sampled farm enterprises. Seventy-five or 60 percent of the poultry businesses had retained earnings to total assets ratios of between negative 7 percent and 35 percent. In 2011, sixty-two farm or 49.6 percent of the farm businesses had negative ratios between 37 and 8 percent while 50.4 percent or 63 farm units had ratios between negative 7 percent and 35 percent. In 2012, fifty-four or 43.2 percent had negative retained earnings to total assets ratios of between 37 and 8 percent while 71 farms or 56.8 percent had ratios of between negative 7 percent and 35 percent. When compared with the mean retained earnings to total assets ratio, over 50 percent of the sampled farm businesses in all the year had ratios between the average ratios of one (1) percent. The low level of retained earnings to total assets ratio may be interpreted to 
mean either that majority of the sampled farm businesses were young or that a greater proportion of their assets or operations were financed through borrowings. It also implies a closer watch on, monitoring and management of this ratio for effective operation of these farm businesses by the poultry entrepreneurs.

\section{EBIT to total assets ratio $\left(\mathbf{X}_{3}\right)$}

The minimum earnings before interest and tax (EBIT) to total assets ratio of 65 percent for the sampled farm businesses was negative. The maximum was positive and stood at 60 percent. The mean EBIT to total assets ratio was 2 percent with a standard deviation of 28 percent.

Table 4. Sampled poultry farms computed EBIT /total assets ratio $\left(\mathrm{X}_{3}\right)$

\begin{tabular}{llll}
\hline & 2010 & 2011 & 2012 \\
\hline Ratio class (pooled) & No. farms (percent) & No. farms(percent) & No. farms(percent) \\
\hline$-65--4$ & $17(13.6)$ & $15(12)$ & $14(11.2)$ \\
$-3--5$ & $41(32.8)$ & $44(35.2)$ & $45(36)$ \\
$-4-21$ & $33(26.4)$ & $36(28.8)$ & $33(26.4)$ \\
$22-47$ & $21(16.8)$ & $22(17.6)$ & $27(21.6)$ \\
$48-73$ & $12(9.6)$ & $8(6.4)$ & $6(4.8)$ \\
Total & $\mathbf{1 2 5 ( 1 0 0 )}$ & $\mathbf{1 2 5}(\mathbf{1 0 0})$ & $\mathbf{1 2 5}(\mathbf{1 0 0})$ \\
\hline
\end{tabular}

Source: Survey data.

Table 4 shows the size distribution of the EBIT to total assets ratio. As the table indicates, in 2010, ninety-one or 72 percent of the sampled farms had EBIT to total assets ratio of between minus 65 percent to 21 percent while 34 farms or 28 percent had ratios between 22 percent and 73 percent. in 20111 and 2012, the number of farms with ratios between minus 65 percent and 21 percent were 95 or 76 percent and 92 or 73 percent, respectively. Thirty or 24 percent farms businesses in 2011 and 33 or 26.4 percent farm business in 2012, had EBIT to total assets ratios between 22 percent and 73 percent. With the high proportion of farms having low EBIT to total assets ratio in all the years, it might, probably, be deduced that the earning power of a great proportion of the poultry farms is weak.

\section{Book value of equity to total debts ratio $\left(\mathrm{X}_{4}\right)$}

The minimum value of book equity value to total debts ratio was negative and stood at 36 percent while the maximum ratio was 42 percent. The mean book value of equity to total debts ratio was 6 percent with a standard deviation of 18 percent.

Table 5. Sampled poultry farms computed equity value /total debts ratio $\left(\mathrm{X}_{4}\right)$

\begin{tabular}{llll}
\hline & 2010 & 2011 & 2012 \\
\hline Ratio class (pooled) & No. farms (percent) & No. farms(percent) & No. farms(percent) \\
\hline$-36--2$ & $21(16.8)$ & $25(20)$ & $26(20.8)$ \\
$-21--5$ & $10(8)$ & $13(10.4)$ & $13(10.4)$ \\
$-4-12$ & $42(33.6)$ & $43(34.4)$ & $46(36.8)$ \\
$13-29$ & $43(34.4)$ & $32(25.6)$ & $30(24)$ \\
$3-46$ & $9(7.2)$ & $12(9.6)$ & $10(8)$ \\
Total & $\mathbf{1 2 5}(\mathbf{1 0 0})$ & $\mathbf{1 2 5 ( 1 0 0 )}$ & $\mathbf{1 2 5}(\mathbf{1 0 0})$ \\
\hline
\end{tabular}

Source: Survey data.

Table 5 indicates the size distribution of the book value of equity to total debts ratio. The table shows that in 2010, 2011 and 2012, seventy three or 58.4 percent, 81 or 64.8 percent and 85 or 68 percent, respectively, of the book value of equity to total debts ratios of between negative 36 percent to 12 percent. Also in 2010, 2011 and 
2012, fifty or 41.6 percent, 44 or 35.2 percent and 40 or 32 percent, respectively, of poultry farm businesses had book value of equity to total debts ratio of between 13 percent and 46 percent.

\section{Sales to total assets ratio $\left(\mathbf{X}_{5}\right)$}

The minimum sales to total assets ratio for the three years studied was 1.26 while the maximum was 3.51 . The mean ratio was 1.78 with a standard deviation of 0.42 .

Table 6. Sampled poultry farms computed sales /total assets ratio $\left(\mathrm{X}_{5}\right)$

\begin{tabular}{llll}
\hline & 2010 & 2011 & 2012 \\
\hline Ratio class (pooled) & No. farms (percent) & No. farms(percent) & No. farms(percent) \\
\hline $1.26-1.71$ & $59(47.2)$ & $60(48)$ & $62(49.6)$ \\
$1.72-2.17$ & $45(36)$ & $46(36.8)$ & $49(39.2)$ \\
$2.18-2.63$ & $12(9.6)$ & $7(5.6)$ & $7(5.6)$ \\
$2.64-3.09$ & $6(4.8)$ & $7(5.6)$ & $3(2.4)$ \\
$3.1-3.55$ & $3(2.4)$ & $6(4.8)$ & $4(3.2)$ \\
Total & $\mathbf{1 2 5}(\mathbf{1 0 0})$ & $\mathbf{1 2 5 ( 1 0 0 )}$ & $\mathbf{1 2 5}(\mathbf{1 0 0})$ \\
\hline
\end{tabular}

Source: Survey data.

From table 6, it can be seen that in 2010, 2011 and 2012, one hundred and four or 83.2 percent, 106 or 84.8 percent and 111 or 88.8 percent, of the sampled farm businesses respectively, had sales to total assets ratios of between 1.26 and 2.17. While 21 or 16.8 percent, 19 or 15.2 percent and 14 or 11.2 percent in 2010, 2011 and 2012 respectively of the sampled farm businesses had ratios between 2.18 and 3.55 .

\section{Distribution of computed Altman's Z-scores}

Table 7. Distribution of sampled poultry farms computed Altman's Z-scores

\begin{tabular}{llll}
\hline & 2010 & 2011 & 2012 \\
\hline Z-scores' class (pooled) & No. farms (percent) & No. farms(percent) & No. farms(percent) \\
$-60-47$ & $14(11.2)$ & $17(13.6)$ & $12(9.6)$ \\
$48-1.55$ & $46(36.8)$ & $39(31.2)$ & $41(32.8)$ \\
$1.56-2.63$ & $30(24)$ & $38(30.4)$ & $35(28)$ \\
$2.64-3.71$ & $24(19.2)$ & $20(16)$ & $22(18.4)$ \\
$3.72-4.79$ & $11(8.8)$ & $11(8.8)$ & $15(12)$ \\
Total & $\mathbf{1 2 5 ( 1 0 0 )}$ & $\mathbf{1 2 5}(\mathbf{1 0 0})$ & $\mathbf{1 2 5}(\mathbf{1 0 0})$ \\
\hline
\end{tabular}

Source: Survey data.

Table 7 shows the distribution of the computed Altman's Z-scores for the sampled poultry farm businesses. The table reveals that in 2010,60 or 47.8 percent of farm enterprises had Z-scores between minus 0.60 to 1.55 . In 2011 and 2012, fifty six or 44.8 percent and 53 or 42.4 percent, respectively of the farms had Z-scores between negative 0.60 and 1.55 . The table also shows that 30 or 24 percent, 38 or 30.4 percent and 35 or 28 percent in 2010, 2011 and 2012, respectively, of the sampled farm businesses had Z-scores between 1.56 and 2.63. The table further indicates that 35 or 28 percent, 31 or 27 percent and 37 or 30.4 percent in 2010, 2011 and 2012, respectively, of the sampled farms had computed Z-scores between 2.64 and 4.79 farms. 


\section{Financial health status based on Altman's Z-score criterion}

Table 8. Sampled poultry farms' financial health status based on Altman's Z-score criterion

\begin{tabular}{llll}
\hline & 2010 & 2011 & 2012 \\
\hline Z-scores' class & No. farms (percent) & No. farms(percent) & No. farms(percent) \\
\hline Greater than 2.9 & $21(16.8)$ & $19(15.2)$ & $23(18.4)$ \\
1.81 to 2.9 & $24(19.2)$ & $16(12.8)$ & $14(11.2)$ \\
Less than 1.81 & $80(64)$ & $90(72)$ & $88(70.4)$ \\
Total & $\mathbf{1 2 5 ( 1 0 0 )}$ & $\mathbf{1 2 5 ( 1 0 0 )}$ & $\mathbf{1 2 5 ( 1 0 0 )}$ \\
\hline
\end{tabular}

Source: Survey data.

Table 8 shows the financial health status of sampled farm businesses based on Altman's Z-score criterion. The table reveals that in 2010, 2011 and 2012, eighty or 64 percent, 90 or 73 percent and 88 or 70.4 percent, respectively, of the sampled farms had Z-scores less than 1.81 while 24 or 19.2 percent, 16 or 12.8 percent and 14 or 11.2 percent, respectively, had Z-scores greater than 1.81 but less than 2.9. The table further reveals that 21 or 16.8 percent, 19 or 15.2 percent and 23 or 18.4 percent in 2010, 2011 and 2012, respectively, of the sampled farms had Z-scores greater than 2.9. The financial health status implications is that in 2010, 2011 and 2012, sixty four percent, 72 percent and 70.4 percent, respectively, of the sampled farms were financially distressed while 16.2 percent, 15.2 percent and 18.4 percent, respectively, were financially strong. The financial health status of 24 or 19.2 percent, 16 or 12.8 percent, respectively, of the sampled farms could not be predicted because their Z-scores fell within the grey zone of 1.81 to 2.9 of Altman's criterion.

\section{Conclusion}

This paper investigated the financial health status of small scale poultry businesses in Delta State, Nigeria using Altman's Z-score model. The empirical study was undertaken to assess the solvency and hence future survivability of small scale poultry enterprises in the State in recognition of the critical role which small and medium scale enterprises play in food production, employment generation, poverty alleviation and national development. Financial data were extracted from the financial statements of 125 small scale poultry farms purposively selected from farms operating in the State and incorporated with the Nigerian Corporate Affairs Commission as limited liability agribusinesses. The study shows that in 2010, 60 or 47.8 percent of farm enterprises had Z-scores between minus 0.60 to 1.55 . In 2011 and 2012, fifty six or 44.8 percent and 53 or 42.4 percent, respectively of the farms had Z-scores between negative 0.60 and 1.55 . The table also shows that 30 or 24 percent, 38 or 30.4 percent and 35 or 28 percent in 2010, 2011 and 2012, respectively, of the sampled farm businesses had Z-scores between 1.56 and 2.63. The study further indicates that 35 or 28 percent, 31 or 27 percent and 37 or 30.4 percent in 2010, 2011 and 2012, respectively, of the sampled farms had computed Z-scores between 2.64 and 4.79 farms. The study, therefore, concludes that in 2010, 2011 and 2012, sixty four percent, 72 percent and 70.4 percent, respectively, of the sampled farms were financially distressed while 16.2 percent, 15.2 percent and 18.4 percent, respectively, were financially strong. It is thus recommended that remedial measures such as entrepreneurial training programmes on effective working capital management, farm assets management, farm finance and operations management for small scale poultry businesses in the State to obviate failure and enhance survivability. The study also recommends the use of Altman's Z-score by small scale investors as a technique for monitoring the financial health of their agribusinesses to prevent the ugly consequences of bankruptcy and liquidation.

\section{References}

Ani, W. U., \& Ugwunta, D. O. (2012). Predicting Corporate Business Failure in the Nigerian Manufacturing Industry. European Journal of Business and Management, 4(10), 86-93.

Ani, W. U., \& Ugwunta, D. O. (2012). Detecting Early Warming Bank Distress Signals in Nigeria: A Multi Discriminant Analysis Approach. Journal of Accounting Research, 3(6), 35-46.

Aremu, M. A., \& Adeyemi, S. L. (2011). Small and Medium Scale Enterprises as A Survival Strategy for Employment Generation in Nigeria. Journal of Sustainable Development, 4(1), 200-206.

Bhatt, S. N. (2012). Capital Structure and Turnaround Strategies using Altman's Z-score Models. Asian Journal 
of Research in Business, Economic and Management, 2(7), 102-113.

Gambo, A. I., \& Yusuf, M. W. (2010). An Application of Multivariate Analysis in Modeling StudentsPlacement in Nigerian Higher Institutions. Journal of Mathematics and Statistics, 6(3), 350-356. http://dx.doi.org/10.3844/jmssp.2010.350.356

Krishna, C. V. (2005). Measuring Financial Distress of IDBI Using Altman Z-Score Model. The ICFAI Journal of Bank Management, 6(3), 7-17.

Li, J. (2011). Prediction of Corporate Bankruptcy from 2008 Through 2011. Journal of Accounting and Finance, $12(1), 31-41$.

Olaniyi, T. A. (2007). Predicting Potential of Failure in Nigeria Banking Sector: A Comparative Analysis of First Bank PLC, and Trade Bank PLC. Journal of Management and Social Sciences, Babcock University, 6(1), 64-73.

Onyeiwu, C. (2012). Financial Statement as Instrument for Predicting Corporate Health in Nigeria. Paper Presented at $4^{\text {th }}$ Annual Conference on the Department of Finance, University of Lagos.

Satish, Y. M., \& Janakiram, B. (2011). Turnaround Strategy Using Altman Model as a Tool in Solar WaterHeater Industry in Karnataka. International Journal of Business and Management, 6(1), 199-206.

Selvam, M., Vanitha, S., \& Babu, M. (2004). A Study on Financial Health of Cement Industry-Z Score analysis. The Management Accountant, 39(7), 591-593.

Sulphey, M. M., \& Nisa, S. (2013). The Analytical Implication of Altman's Z-score Analysis of BSE Listed Small CAP Companies. Journal of Commerce and Management Perspective, 2(4), 45-155.

Suzanne, K. H., Kay, A. H., \& Larry, W. H. (2010). A Study of the Efficacy of Altman's Z to Predict bankruptcy of Special Retail Firms Doing Business in Contemporary Times. Journal of Economics and Business, 3(1).

\section{Copyrights}

Copyright for this article is retained by the author(s), with first publication rights granted to the journal.

This is an open-access article distributed under the terms and conditions of the Creative Commons Attribution license (http://creativecommons.org/licenses/by/3.0/). 